\title{
Language acquisition 3-Year-Old Children Through Visual Audio Learning Media During Covid-19 Pandemics
}

\author{
Rita Kumala Sari ${ }^{1}$ \\ ${ }^{1}$ Indonesian Education Department, Universitas Borneo Tarakan, Tarakan, Indonesia \\ Corresponding Author* Email: ritakumalaborneo@gmail.com
}

\begin{abstract}
This research was a descriptive qualitative study describing language acquisition in children aged 2 years and 8 months. The purpose of this study is to provide an overview of the use of audio-visual learning media in language acquisition for children aged 2.8 years in the form of vocabulary and sentences during the covid 19 periods. This research uses a descriptive qualitative method with a case study approach. This research is about a girl, Farjanah, who is also the author's child's first daughter. Data collection was carried out for four months starting from June to August 2020, when Farjanah was two years eight months old - 2 years ten months old. The form of this data is words and sentences in speech and dialogue from the subject. The data collected technique used documentation by noting and recording using the Samsung A51 mobile phone. All data is classified and then analyzed according to type. From the results of the analysis of research on the use of animated videos in acquiring vocabulary, among others: (1) Language acquisition in the wording of children aged 2.8 years is more dominated by nouns and numbers. (2) Language acquisition in sentences of children aged 2.8 years is dominated by positive sentences with reference and followed by interrogative sentences.
\end{abstract}

Keywords: Learning Media, Language Acquisition, Covid-19

\section{INTRODUCTION}

Humans acquire language as a means of communication from birth to five, known as language acquisition. Language acquisition is a process that takes place in the brain of children when they acquire their first language or their mother tongue. The term acquisition corresponds to the English term acquisition, which is the process of mastery of the speech carried out by a child naturally when he learns his native language. The language obtained can be in vowels, namely in spoken language or speech sounds, and sign. Meanwhile, children's language is sometimes difficult to translate because children generally still use language structures that are always chaotic and are still experiencing a transitional stage in speaking, making it difficult for the partners to understand. To become a participant in the child and to be able to understand the meaning of the child's speech, the speech partner must master the conditions or the surrounding environment. When young children talk, they use the media around them to clarify what they are saying.

The process of acquiring children's language can be influenced by external factors and from factors within the child himself. Language acquisition obtained from external factors is controlled by playing area, family, and school environment. Because human nature is a social being, it requires other people to meet their needs in interacting with everything around them. Through these environmental factors, children can explore language knowledge during their development. The other influence of factors in children is that a child is born with the genetic capacity to acquire the language around him. The language acquisition for each child is different because humans live things with varying characteristics and are unique.

This study uses psycholinguistic theory, language acquisition, children's language development, lexicon, and lexicon acquisition. Psycholinguistics is a 
collaboration of psychology and linguistics whose field of study is language, which is a phenomenon that is always present in all activities of human life.

Psycholinguistics describes the psychological processes that occur when a person utters the sentences he hears while communicating and how the language ability is acquired by man [1]. [2] Psycholinguistics is the science that studies the mental processes that humans go through in their language. So psycholinguistics in detail studies four main topics, namely: comprehension, production, biological foundation, language acquisition; Language acquisition is the process of language mastery that a child does naturally learns their mother tongue (native language). Language acquisition is related to how humans can perceive and then understand the utterances of others. Two processes occur when a child acquires his first language [1] namely the process of competence and the process of performance. Hypotheses related to children's language acquisition, namely: conscience hypothesis, tabular taste, and cognitive hypothesis. Child language development there are three views or theories about child language development.

Early children are children aged 0-8 years. [3] Early childhood is a child aged between 3-6 years. In contrast, [4] the nature of early childhood is a unique individual where he has a pattern of growth and development in the physical, cognitive, socioemotional aspects, creativity, language, and communication that are specific to the stage that the child is going through. At this age, the child begins to develop a sense of curiosity through language. In this case, the learning media will help the language acquisition process's effectiveness in early childhood. Using learning media, especially audio-visual media, aims to motivate the child's learning so that it is easy for the child to capture the content, that is, increasing vocabulary.

Meanwhile, in this study, the researcher examined a 3-year-old child named Farjanah Ilham, the first child of Mr. Abu Talib Ilham, S.E, and Mrs. Rita Kumala Sari, M.Pd. The activity and agility of Farjanah make researchers want to research to find out the acquisition of good language in the form of vocabulary and sentences they get. In addition to the size of a child his age, Farjanah can already master some children's songs and memorize some prayers. This condition is inseparable from Farjanah's frequent learning from audio-visual media in the form of youtube and television. In addition to family factors and the media, the environment is conducive to increasing vocabulary and sentences in the language acquisition process.

Currently, Indonesia is experiencing a major disaster in the form of the Covid 19 pandemic significantly spread throughout the world. The government and the Ministry of Education have appealed to the public to work and study from home. It also triggers parents to be more active and enthusiastic in teaching their children to learn from home. By using audio-visual media, both learning by using Youtube and television, children can learn from home. With this problem, "the author wants to examine the use of audio-visual learning media in language acquisition for children aged three years during the Covid 19 pandemic."

\section{METHOD}

The research method used in this research is descriptive qualitative. [5] [6] The qualitative descriptive research method is appropriate to use in this study because it is considered appropriate to describe systematically, factually, and accurately regarding the acquisition of Indonesian vocabulary and sentences spoken to children aged three years. Qualitative descriptive research is research conducted based on existing facts or phenomena that are empirically alive in speakers. What is produced or recorded in the provision of language can be said to be like a portrait of exposure as it is [7].

This research was conducted at home, seeing Indonesia's current situation is being hit by the coronavirus. This research was taken when the child was playing and doing daily activities with his family. The research techniques used in this research are recording techniques and field notes. The recording method is used to make it easier for the author to transcribe the data obtained. This recording method is done along the writer conducts research both in the learning process and outside the learning process. Audio recording is done using a recording device in the form of a Samsung A51 mobile phone with $10 \mathrm{~GB}$ of memory. The instrument used to record was a memory card. The vocabularies and sentences were recorded once Farjanah produced them. Then the data is analyzed according to the vocabulary and sentences obtained based on the type of vocabulary.

This research instrument was the researcher which [8] the position of researchers in qualitative research is as a planner, implementer, data collection, data interpretation, and reporting the results of the research itself.

\section{RESULT AND DISCUSSION}

\subsection{Vocabulary Acquisition}

Based on the results of field research on the use of audio-visual learning media in the acquisition of the language of a 3-year-old child during the covid-19 pandemic at home, the researchers found data in the form of vocabulary mastered by the child Farjanah Farjanah Ilham. The acquisition of the language is presented in the table as follows: 
Table 1. Vocabulary Acquisition Data

\begin{tabular}{|c|c|c|}
\hline No & $\begin{array}{l}\text { Indoensia } \\
\text { Word } \\
\text { classes }\end{array}$ & Gained Vocabulary \\
\hline 1 & Verb & $\begin{array}{l}\text { Eat, drink, sleep, walk, work, bathe, } \\
\text { massage, take, lift, cook, wash, run, } \\
\text { write, sleep, wipe, bribe, stand }\end{array}$ \\
\hline 2 & Adjective & $\begin{array}{l}\text { fat, beautiful, handsome, ugly, skinny, } \\
\text { hurt, cough, hot, tall, short, small. }\end{array}$ \\
\hline 3 & Noun & $\begin{array}{l}\text { Body, lips, hair, mouth, teeth, } \\
\text { forehead, eyebrows, eyes, ears, nose, } \\
\text { hands, belly, cheek, nails, fingers, } \\
\text { legs, bicycles, motorbikes, cars, } \\
\text { planes, trains, helmets, hand phone, } \\
\text { laptop, refrigerators , television, } \\
\text { cupboard, perfume, powder, oil, } \\
\text { clothes, spoon, comb, clothes, } \\
\text { headscarf, bag, clock, glasses, } \\
\text { blanket, socks, broom, pacifier, milk, } \\
\text { toothbrush, dipper, door, candela, cap, } \\
\text { sandal, tree, branches, oil, earrings, } \\
\text { bracelet, ring, cow, cat, tiger, rat, hog, } \\
\text { horse, goat, bird, chicken, red, pink, } \\
\text { blue, green, brown, bronze, orange, } \\
\text { yellow, black , white, cockroach, } \\
\text { rabbit, elephant, Aci, Samha, Adit, } \\
\text { Athar, Alib, Viona, Fatih, mimi, } \\
\text { mother, sister, ade, ude, brother, ebu, } \\
\text { umi, daddy, Father, grandmother, ain, } \\
\text { fig, persistent, Dimas, Kiki, Dinda, } \\
\text { Bagas, Darsih, Marisa, Ika, Ebi, Indi, } \\
\text { Yoyok, Dear, Wawan, Uud, Retno, } \\
\text { Qolbi, bottle, milk, medicine, bread, } \\
\text { donut, tofu , ice cream, snack, } \\
\text { cookies, porridge, crackers, sweets, } \\
\text { rice, fish, catfish, shrimp, potato, } \\
\text { meatballs, fried noodles, jelly, fruit, } \\
\text { grapes, mango, apples, oranges, pier, } \\
\text { banana, papaya, watermelon, melon, } \\
\text { pumpkin, peanuts, pencil, book, pen, } \\
\text { dates, flowers, spoons, plates, forks, } \\
\text { knives, scissors, paper. Stick, water, } \\
\text { toothbrush soap, toothpaste, } \\
\text { shampoo, Janeva. }\end{array}$ \\
\hline 4 & $\begin{array}{l}\text { Number \& } \\
\text { Letter }\end{array}$ & $\begin{array}{l}\text { one, two, three, four, five, six, seven, } \\
\text { eight, nine, ten, eleven, twelve, } \\
\text { thirteen, fourteen, fifteen, sixteen, } \\
\text { seventeen, eighteen, nineteen, twenty. } \\
\text { a, b, c, d, e, f, g, h, I, j, k, l, m, n, o, p, } \\
\text { q, r, s, t, u, v, w, x, y, zalib , ba, ta, tsa, } \\
\text { jim, ha, ho, da, za, ro ja, sin, sim, so, } \\
\text { do, to zo in, fa qo ka, lam, mi, nun, } \\
\text { wau ha lam, ham ja ya. }\end{array}$ \\
\hline 5 & Pronoun & Farjanah \\
\hline 6 & Adverb & $\begin{array}{l}\text { Morning, afternoon, evening, night, } \\
\text { yesterday, tomorrow. }\end{array}$ \\
\hline 7 & Question & Where, when, how, what \\
\hline 8 & Article & - \\
\hline 9 & Basic word & - \\
\hline 10 & Interjection & - \\
\hline 11 & Conjunction & - \\
\hline 12 & $\begin{array}{l}\text { Repeat } \\
\text { Word }\end{array}$ & $\begin{array}{l}\text { Jalan-jalan, odong-odong, lari-lari, } \\
\text { onde-onde }\end{array}$ \\
\hline 13 & $\begin{array}{l}\text { Derivative } \\
\text { Word }\end{array}$ & - \\
\hline
\end{tabular}

Based on the data table 1, it can be known that the number of Indonesian vocabulary in infants Farjanah Ilham is 17 verbs, 11 adjectives, 175 nouns, 54 words, 1 pronoun, 6 repetitions, 4 question words, while some words such as clothing, introductory words, exclamation words, connecting words, and derivative words (Farjanah) have not understood or have not been able to mention. From the Indonesian vocabulary table above, it can be seen that Farjanah uses more words that have noun elements. It is because children can directly see the object of the word spoken to remember the word that has been taught easily. The repetition of words also heard significantly affects the vocabulary. The use of number words occupies the 2 nd highest order of 54 words. It is caused Farjanah often listen to songs played by their mother related to the numbers $1-10$, say them, and then sing the letters A-Z and Hija'iyah letters by singing or listening to them. [9] Parents Farjanah often guide Farjanah to remember the letters hijariyah and numbers so that the child can master the vocabulary of numbers from beginning to end.

\subsection{Sentence Acquisition}

Apart from acquiring vocabulary, the children of the Farjanah are also able to compose sentences. The produced sentences are composed of no reference and reference. These sentences are obtained from audiovisual media in the form of Powtoon animation media, or youtube in children's songs, prayers, and even children's youtube with high educational value. These sentences are as follows:

Table 2. Sentences with no reference

\begin{tabular}{|c|c|}
\hline No & Sentence \\
\hline 1 & Want to eat \\
\hline 2 & Want to drink \\
\hline 3 & Go for a walk \\
\hline 4 & Want potatoes \\
\hline 5 & Play first \\
\hline 6 & Brush teeth \\
\hline 7 & Drink milk \\
\hline 8 & Eat chicken \\
\hline 9 & Thank you, Ummi \\
\hline 10 & Buy ice cream \\
\hline 11 & Want it \\
\hline 12 & Want to take a pee \\
\hline 13 & Want to work \\
\hline 14 & Comb hair \\
\hline 15 & Take a medicine \\
\hline 16 & Wear a Hijab \\
\hline 17 & Must wear a mask \\
\hline 18 & Want a noodle \\
\hline 19 & Buy mango \\
\hline 20 & Play at Farja's house \\
\hline 21 & Do not get home earlier \\
\hline 22 & Play at Sila's House \\
\hline 23 & Do not forget to wear a mask \\
\hline 24 & Repurchase it tomorrow \\
\hline
\end{tabular}


The table sentences with no reference presents that Farjanah masters verbs more than nouns, adjectives, and adverbs.

Table 3. Sentences with reference

\begin{tabular}{|l|l|}
\hline No & \multicolumn{1}{|c|}{ Sentences } \\
\hline 1 & Fajar studies \\
\hline 2 & It is very delicious \\
\hline 3 & Where are you, grandmother? \\
\hline 4 & Farja is scared \\
\hline 5 & There is a lighting \\
\hline 6 & It is not good \\
\hline 7 & It is completed \\
\hline 8 & There is Tayo \\
\hline 9 & I am stomachache \\
\hline 10 & Farja is sick \\
\hline 11 & There is a package \\
\hline 121 & What is this? \\
\hline 13 & What is that? \\
\hline 14 & It smells good \\
\hline 15 & What smell is it? \\
\hline 16 & It is boiling \\
\hline 17 & It is freezing \\
\hline 18 & It is pink \\
\hline 19 & I am full \\
\hline 20 & Farja wants to come \\
\hline 21 & Be careful, dad! \\
\hline 22 & Where are the cows? \\
\hline 23 & Where is Farja's bag? \\
\hline 24 & Will you work, Ummi? \\
\hline 25 & Farja feels well \\
\hline 26 & Farja is stomachache \\
\hline 27 & Farja wants to go to school \\
\hline 28 & Where is Dimas? \\
\hline 29 & Daddy bought a bicycle \\
\hline 30 & Where are you going, Kiki? \\
\hline 31 & Farja loves Ummi \\
\hline 32 & How does Daddy not get home yet? \\
\hline 33 & My Ummi does not allow \\
\hline 34 & Then we are not friends \\
\hline 35 & When Farja was a child \\
\hline 36 & Farja's cloth has been too small \\
\hline 37 & Farja apologized \\
\hline 38 & Farja cannot make it, Ummi \\
\hline 39 & Ummi help Farja, please \\
\hline 40 & Who is knocking, Ummi? \\
\hline 41 & Farja is full, Ummi \\
\hline 42 & Farja wants to buy Pororo \\
\hline 43 & Farja wants to take a vitamin, Ummi \\
\hline 45 & When Farja grows up \\
\hline 47 & Which one is hurt, Ummi? \\
\hline & Farja is stomachache \\
\hline
\end{tabular}

Based on the three-word sentence table 3, it has shown that there is a combination of words in one sentence, so that in one sentence, it is not dominated by verbs alone but consists of several verbs strung together in one sentence. The data shows that Farjanah dominantly produces positive sentences than question sentences. Question words are words used by children to express children's curiosity about something they see and experience. The question word used is what, who, where, when, and how. [10] [11]These words are often said and repeated many times. When a child enters the age of 3 years, the child has language skills to generalize meanings, create words according to their needs, learn songs from the lyrics they hear through audio-visual media in cell phones, TVs, and laptops.

In addition to the frequently used interrogative sentences, [12] [13] in the acquisition of the language, the children of Nusantara can already use sentences of more than four words. Farjanah can already tell about all the activities they do from morning to evening. Many new words are obtained through audio-visual media. The use of audiovisual media in language acquisition was carried out during the Covid-19 pandemic at home. Farjanah also needs assistance from their parents to direct words that they do not understand. It is done so that the nation's children do not misinterpret the words they get.

\section{CONCLUSIONS}

Language acquisition in 3-year-olds using audiovisual learning media in the form of animated video, youtube, HP, laptop, TV dramatically influences acquiring vocabulary and sentences. By using audiovisual video, the child quickly captures the language both seen and heard. The pronunciation or pronunciation uttered becomes clearer.

From the results of research analysis on the use of animated video in vocabulary acquisition, among others: a. Nouns and numbers more dominate language acquisition in the vocabulary of 3-year olds.

b. Language acquisition in the sentence of a 3-year-old child is more dominated by sentences in the form of question sentences and objects.

The analysis "The Use of Audio-Visual Media in the Acquisition of the Language of Children of the Year During the Covid-19 Pandemic at Home, there should be assisted and supervised by parents on using audio-visual media such as youtube, animated video, or television. It is done to control so that the child's knowledge can be well filtered, especially towards the acquisition of vocabulary that is not yet understood. 


\section{ACKNOWLEDGMENTS}

The title "ACKNOWLEDGMENTS" should be in all caps and should be placed above the references. The references should be consistent within the article and follow the same style. List all the references with full details.

\section{REFERENCES}

[1] A. Chaer, Psikolinguistik: Kajian Teoritik, Jakarta: PT. Rineka Cipta, 2005, p. 5.

[2] S. Dardjowidjojo, Psikolinguistik: Pengantar Pemahaman Bahasa Manusia., Jakarta: Yayasan Obor Indonesia, 2005, p. 7.

[3] D. Yulianti, Bermain Sambil Belajar Sains di Taman Kanak-kanak., Jakarta: PT Indeks, 2010.

[4] L. R. Allen and B. B. Kelly, Transforming the Workforce for Children Birth Through Age 8: A Unifying Foundation, Atlanta: National Academies Press, 2015.

[5] R. B. Johnson and L. Christensen, Educational Rersearch: Quantitative, Qualitative, and Mix Approaches, 6 Edition ed., Singapore: SAGE Publications, Inc., 2017.

[6] S. J. Taylor, R. Bogdan and M. L. DeVault, Intorduction to Qualitative Research Methods: A Guidebook and Resources, 4th Edition ed., Canada: John Wiley \& Sons, Inc., 2016.

[7] Sudaryanto, Metode \& Aneka Teknik Analisis Bahasa (Pengantar Penelitian Wahanan Kebudayaan Secara Linguistik), Yogyakarta: Duta Wacana University Press, 1993, p. 62.

[8] . L. J. Moleong, Metodologi Penelitian Kualitatif., Bandung: PT Remaja Rosdakarya, 2011, p. 168.

[9] N. j. Davidse, . M. T. D. Jong, . A. G. Bus, S. C. J. Huijbregts and. H. Swaab, "Cognitive and environmental predictors of early literacy skills," Read Writ, vol. 24, p. 395, 2011.

[10] S. . P. Brubacher, K. P. Roberts and M. Powell, "Retrieval of episodic versus generic information: Does the order of recall affect the amount and accuracy of details reported by children about repeated events?," Developmental Psychology, vol. 48, no. 1, p. 111, 2012.
[11] . S. P. Brubacher, M. . B. Powell and K. P. Roberts, "Recommendations for interviewing children about repeated experiences," Psychology, Public Policy, and Law, vol. 20, no. 3, p. 325, 2014.

[12] A. Judie, Wong's Essentials of Pediatric Nursing: Second South Asian Edition, Edinburgh: Elsevier Health Sciences, 2018.

[13] W. Nagy and D. Townsend, "Words as Tools: Learning Academic Vocabulary as Language Acquisition," Reading Research Quarterly, vol. 47, no. 1, p. 91, 2012. 